\title{
Karakteristik Peternak Sapi di Sentra Produksi Ternak Potong Di Kabupaten Sorong
}

\section{Characteristics of Cattle Breeders in Beef Cattle Production Centers in Sorong Regency}

\author{
Seblum Indey ${ }^{1)}$, Evi Warintan Saragih ${ }^{2 *}$, dan Budi Santoso ${ }^{2)}$ \\ ${ }^{1)}$ Pascasarjana Program Studi Ilmu Peternakan, Universitas Papua \\ ${ }^{2}$ Program Studi Nutrisi dan Teknologi Pakan Ternak, Fakultas Peternakan, Universitas Papua
}
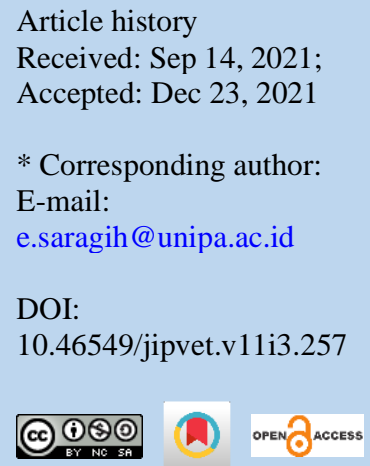

\begin{abstract}
The development of beef cattle needs to be supported by regional potential which includes natural resources and human resources. Sorong Regency is one of the areas for beef cattle development in West Papua Province. This research was conducted for three months, from February to April 2021. The study was conducted in four districts that have a high population of beef cattle in Sorong Regency, West Papua Province. namely Salawati District, Segun District, Mayamuk District, and Moisegen. This research was conducted using a survey method with interview techniques and field observations. Breeding experience, education, age have a relationship with the number of livestock kept. The result showed that farmers were in the productive age and had low education. The traditional rearing with extensive system was a common management practice with less than six cows per household. The experience of rearing cattle, age and education had a correlation with number of cows per household $(r<0.05)$. However, there was not very strong relationship with the variable number of beef cattle. The land area factor does not affect the number of livestock and education was not influence management system. It concluded that livestock activity purposed was not up to business level but it was only for saving purposes.
\end{abstract}

Keywords: Beef cattle; Development; Potential; Production; Sorong

\section{Abstrak}

Pengembangan ternak potong perlu didukung oleh potensi wilayah yang mencakup sumberdaya alam dan sumberdaya manusia. Kabupaten Sorong merupakan salah satu wilayah pengembangan ternak potong di Provinsi Papua Barat. Penelitian dilakukan di empat distrik yang memiliki populasi ternak sapi potong yang cukup tinggi di Kabupaten Sorong Provinsi Papua Barat. yaitu Distrik Salawati, Distrik Segun, Distrik Mayamuk, dan Moisegen, pada bulan Februari sampai dengan April 2021. Penelitian ini dilakukan menggunakan metode survei dengan teknik wawancara dan observasi lapangan. Kriteria responden pada penelitian ini adalah memiliki sapi > 3 ekor dan memiliki pengalaman beternak lebih dari 3 tahun. Penentuan jumlah sampel menggunakan rumus Slovin. Hasil penelitian menunjukkan bahwa karakteristik peternak antara lain: berada pada usia produktif, memiliki pendidikan yang cukup rendah, pengalaman beternak yang cukup lama dan tingkat kepemilikan ternak yang rendah. Sistem pemeliharaan ternak bersifat tradisional dengan pemberian pakan dan pengobatan seminimal mungkin. Pengalaman beternak, pendidikan, umur memiliki hubungan dengan jumlah ternak yang dipelihara. Hal ini ditunjukkan dengan nilai koefiesien korelasi $\mathrm{r}=(\mathrm{r}<0.05)$. Pengalaman beternak dan pendidikan memiliki keeratan hubungan yang tidak terlalu kuat terhadap variabel jumlah ternak sapi potong. Faktor luas lahan tidak mempengaruhi jumlah ternak yang dipelihara. Hal ini dikarenakan sistem pemeliharaan yang dilakukan peternak dominan dengan sistem umbar terbatas dan pemberian pakan ditambah dari 
sumber lain seperti pinggir jalan dan sumber lain. Faktor luas lahan tidak mempengaruhi jumlah ternak yang dipelihara. Berdasarkan hasil penelitian ini dapat disimpulkan bahwa peternak di sentra peternakan sapi Kabupaten Sorong masih bersifat tradisional yang bertujuan untuk tabungan keluarga dan secara umum belum berorientasi bisnis.

Kata kunci: Pengembangan; Potensi; Produksi; Sapi potong; Sorong.

\section{PENDAHULUAN}

Kabupaten Sorong merupakan salah satu daerah yang di tetapkan sebagai kawasan pengembangan sapi potong di Provinsi Papua Barat (Kepmentan Nomor 472/Kpts/RC.040/6/2018). Berdasarkan data Dinas Peternakan dan Kesehatan Hewan Kabupaten Sorong tahun 2019, populasi sapi potong di Kabupaten Sorong sebanyak 24.233 ekor. Empat distrik di Kabupaten Sorong yang memiliki populasi ternak sapi potong cukup besar yaitu Distrik Salawati, Distrik Segun, Distrik Mayamuk dan Distrik Moisegen dengan populasi sapi potong berturut-turut 8.390, 4.326, 3.871 dan 2.291 ekor (Dinas Peternakan dan Kesehatan Hewan Kabupaten Sorong, 2019).

Sumber daya lahan, pakan dan sumber daya manusia cukup tersedia di Kabupaten Sorong yang menunjang pengembangan usaha ternak potong. Ketersediaan sumber daya lahan pertanian yang limbahnya dapat digunakan sebagai sumber pakan ternak yaitu padi, jagung, ubi-ubian, kacang tanah, kacang hijau, kedelai dapat mendukung pengembangan peternakan sapi potong. Lahan untuk menunjang peternakan adalah lahan garapan, tegalan, kebun dan padang rumput. Jumlah petani yang mengusahakan ternak sebagai usaha sampingan cukup tinggi dengan sistem pemeliharaan yang bersifat ekstensif.

Karakteristik peternak dibangun berdasarkan unsur-unsur perilaku, psikografis dan demografis. Karakteristik demografis merupakan salah satu perubah yang sering digunakan untuk melihat kemampuan berkomunikasi dan memilih media yang berhubungan erat dengan sumber-sumber informasi. Faktor-faktor demografis adalah umur, pendapatan, pendidikan, pengalaman dan kekosmopolitan (Wardhani, 1994)

Pengembangan usaha ternak sapi dipengaruhi oleh karakteristik peternaknya.
Kemampuan peternak dalam mengelola usaha ternaknya akan mempengaruhi produktivitas ternak. Usaha peternakan akan berkembang apabila peternak berupaya merubah cara berpikirnya dan menumbuhkan karakteristiknya dengan memiliki sejumlah pengetahuan praktis yang berkaitan dengan usaha peternakan. Pengetahuan praktis dapat diperoleh dari pendidikan non formal, memperoleh berbagai informasi dari berbagai sumber, memanfaatkan berbagai media, memperluas pengalamannya, kreatif, inovatif dan berani mengambil keputusan dari kaidah normal. Kunci keberhasilan usaha peternakan ditentukan kemampuan pelaku usaha untuk menyerap informasi yang ada. Informasi merupakan faktor yang penting dalam pengkayaan pengetahuan peternak (Tomatala, 2004). Uraian ini menunjukkan pentingnya karakteristik peternak dalam pengembangan usaha peternakan. Informasi Penelitian ini bertujuan untuk menggali karakteristik peternak sapi potong di Kabupaten Sorong. Informasi ini berguna untuk instansi terkait dalam pengembangan peternakan sapi potong di Kabupaten Sorong.

\section{MATERI DAN METODE}

\section{TEMPAT DAN WAKTU}

Penelitian ini dilaksanakan selama tiga bulan yaitu bulan Februari sampai dengan April 2021. Penelitian dilakukan di empat distrik yang memiliki populasi ternak sapi potong yang cukup tinggi di Kabupaten Sorong Provinsi Papua Barat yaitu Distrik Salawati, Distrik Segun, Distrik Mayamuk, dan Distrik Moisegen.

\section{Metode PENELITIAN}

Penelitian ini dilakukan menggunakan metode survei dengan teknik wawancara dan observasi lapangan. Peternak sapi pada keempat distrik merupakan sumber data primer 
yang yang dikumpulkan dengan mewawancari peternak dengan menggunakan quisioner. Data yang dikumpulkan berupa faktor demografis antara lain umur peternak, pendidikan peternak, jumlah ternak, pengalaman beternak, modal usaha, dan pekerjaan utama. Penentuan sampel penelitian secara purposive sampling terhadap empat distrik yang merupakan kantong ternak di Kabupaten Sorong dan penentuan jumlah sampel per distrik dihitung dengan menggunakan rumus Slovin (Setiawan, 2007) sebagai berikut:

$$
n=\frac{N}{N \cdot d^{2}+1}
$$

Keterangan: $\mathrm{n}=$ ukuran sampel

$$
\begin{aligned}
\mathrm{N} & =\text { ukuran populasi } \\
\mathrm{d} & =\text { galat pendugaan }(5 \%)
\end{aligned}
$$

Dengan demikian jumlah peternak pada masing-masing distrik bergantung pada jumlah peternak pada setiap distrik. Kriteria peternak yang diambil sebagai sampel adalah peternak yang memiliki sapi potong lebih dari tiga ekor dan memiliki pengalaman beternak lebih dari tiga tahun.

\section{ANALISIS DATA}

Data yang diperoleh dianalisis secara deskriptif dan disajikan dalam bentuk tabel untuk menggambarkan karakteristik peternak sapi potong. Analisis korelasi dan regresi linier sederhana digunakan untuk mengetahui hubungan antar faktor karakteristik peternak ternak sapi potong.

\section{HASIL DAN PEMBAHASAN}

UMUR PETERNAK
Sebaran umur peternak di sentra produksi ternak potong di Kabupaten Sorong berada pada usia produktif. Tabel 1 menunjukan bahwa rata-rata umur peternak 50-60 tahun memiliki persentase paling tinggi (47\%). Namun demikian umur peternak diatas umur 30 tahun dan di bawah umur 70 tahun mendominasi sebaran peternak sapi dengan persentasi $92,5 \%$. Hal ini menunjukkan bahwa umur peternak di Kabupaten Sorong berada pada kategori produktif yaitu pada umur 20-65 tahun. Badan Pusat Statistik (BPS) dan World Health organisaziton (WHO) menyatakan usia produktif berada pada kisaran 15-64 tahun. Selanjutnya Siswati (2000) menyatakan bahwa umur antara 30 tahun sampai 60 tahun merupakan usia produktif. Dengan demikian dapat disimpulkan bahwa peternak memiliki kemampuan fisik dan tenaga yang masih kuat untuk bekerja mengelola usaha taninya. Padmowihardjo (1994) menyatakan, setelah mencapai usia 55 atau 60 tahun, kemampuan belajar dan berpengalaman semakin berkurang. Hal ini berarti bahwa umur mempengaruhi kompetensi dan kinerja peternak. Seorang petani ternak dapat diharapkan mampu melakukan suatu kegiatan secara optimal pada usia produktif (Winarso, 2008). Peternak dengan usia tidak produktif hanya $5 \%$ dari total peternak dan untuk kategori usia ini, aktivitas beternak mendapat bantuan tenaga kerja dari anggota keluarga yang lebih muda sehingga kegiatan beternak dan bertani secara umum tetap berjalan dengan baik. Sebaran umur peternak di sentra produksi ternak potong di

\begin{tabular}{|c|c|c|c|c|c|c|}
\hline \multirow{2}{*}{$\begin{array}{l}\text { Umur } \\
\text { (Tahun) }\end{array}$} & \multicolumn{4}{|c|}{ Peternak/Distrik (Orang) } & \multirow{2}{*}{ Jumlah } & \multirow{2}{*}{ Persentase } \\
\hline & Mayamuk & Salawati & Moisigin & Segun & & \\
\hline $20-30$ & 0 & 0 & 1 & 0 & 1 & 1,25 \\
\hline $31-40$ & 2 & 0 & 1 & 1 & 4 & 5,00 \\
\hline $41-50$ & 4 & 2 & 5 & 5 & 16 & 20,00 \\
\hline $51-60$ & 7 & 12 & 10 & 9 & 38 & 47,50 \\
\hline $61-70$ & 6 & 6 & 3 & 5 & 20 & 25,00 \\
\hline $71-85$ & 1 & 0 & 0 & 0 & 1 & 1,25 \\
\hline \multicolumn{5}{|c|}{ Total } & 80 & 100,00 \\
\hline
\end{tabular}
Kabupaten Sorong disajikan pada Tabel 1.

Tabel 1. Sebaran Umur Peternak di Sentra Produksi Ternak Potong di Kabupaten Sorong 


\section{TINGKAT PENDIDIKAN}

Pada umumnya peternak di sentra produksi ternak potong di Kabupaten Sorong memiliki tingkat pendidikan yang rendah. Sebagaian besar peternak $(76,25 \%)$ memiliki pendidikan setara sekolah menengah pertama dan sekolah dasar. Peternak dengan pendidikan pada level perguruan tinggi hanya $3,75 \%$. Hal ini sejalan dengan hasil penelitian Hidayah et al. (2019) yang melaporkan bahwa tingkat pendidikan peternak kambing di Desa Hargotirto Kabupaten Kulon Progo pada umumnya rendah yaitu sekolah dasar. Peternak juga masih terbatas dalam mengikuti pendidikan non formal dibidang peternakan, penyuluhan dan pelatihan. Kurangnya informasi tentang pendidikan non formal menyebabakan peternak tidak mengetahui adanya program tersebut. Keterlibatan masyarakat pada kegiatan dibidang peternakan terbatas pada kegiatan langsung di lapangan seperti inseminasi buatan (IB). Namun kegiatan ini tidak melibatkan semua peternak. Hanya $5 \%$ dari total responden yang terlibat pada kegiatan IB. Tingkat pendidikan berkaitan erat dengan pengembangan dan penerimaan inovasi dalam usaha ternak potong. Halim (2017) menyatakan bahwa tingkat pendidikan berpengaruh secara simultan terhadap motivasi beternak sapi potong. Tingkat pendidikan peternak di sentra produksi ternak potong di Kabupaten Sorong disajikan pada Tabel 2.

\section{Tabel. 2. Sebaran Tingkat Pendidikan Peternak di Sentra Produksi Ternak Potong di Kabupaten} Sorong

\begin{tabular}{lcrrrrrr}
\hline \multirow{2}{*}{ Tingkat Pendidikan } & \multicolumn{3}{c}{ Responden/Distrik (Orang) } & \multirow{2}{*}{ Jumlah } & Persentase \\
\cline { 2 - 5 } & Mayamuk & Salawati & Moisigin & Segun & & \\
\hline Tidak Sekolah & 5 & 4 & 7 & 5 & 21 & 26,25 \\
SD & 8 & 12 & 7 & 13 & 40 & 50,00 \\
SMP & 4 & 2 & 1 & 1 & 8 & 10,00 \\
SMA & 3 & 0 & 4 & 1 & 8 & 10,00 \\
PT & 0 & 2 & 1 & 0 & 3 & 3,75 \\
Non Formal bidang & 0 & 0 & 0 & 0 & & 0 \\
peternakan & & & & & 80 & 100,00 \\
\hline
\end{tabular}

Pengetahuan dan ketrampilan beternak yang dimiliki peternak sangat terbatas. Informasi tentang usaha peternakanpada umumnya diperoleh dari sesama peternak. Hal ini menunjukkan bahwa pengetahuan dan ketrampilan beternak terbatas pada pengetahuan yang dimiliki komunitas peternak saja. Murwanto (2008) menyatakan bahwa tingkat pendidikan peternak merupakan indikator kualitas penduduk dan merupakan peubah kunci dalam pengembangan sumberdaya manusia. Tingkat pendidikan peternak dan ketrampilan yang memadai diharapakan dapat berdampak pada peningkatan kinerja dan kemampuan managemen usaha peternakan yang dijalankan. Peternak yang memiliki pengetahuan dan keterampilan yang baik akan mampu dan berpengalaman dalam menjalankan usaha taninya. Hidayah et al., (2019) menemukan bahwa tingkat pendidikan merupakan salah satu faktor yang berpengaruh terhadap adopsi teknologi pemeliharaan ternak kambing. Selanjutnya, menurut Suratiyah (2006) bahwa kecakapan seseorang menentukan kinerja seseorang, lebih cakap tentu prestasinya akan lebih tinggi bila dibandingkan dengan yang kurang cakap. Kecakapan ditentukan oleh pendidikan, pengetahuan dan pengalaman seseorang.

\section{PEKERJAAN UTAMA}

Pekerjaan adalah suatu usaha yang bertujuan untuk mendapatkan penghasilan Pekerjaan seseorang adalah faktor yang menentukan tingkat keberhasilan seseorang itu dalam karirnya, ada sebagian orang yang memilih untuk menjadi pegawai di pemerintahan dan ada sebagian orang yang lebih memilih untuk berwiraswasta (Sagi at al., 2018). Pada umumnya pekerjaan utama 
responden adalah petani. Mayoritas penduduk $(88,75 \%)$ melakukan kegiatan bertani dalam arti luas. Hal ini mencakup kegiatan pertanian dan peternakan yang dikelola secara bersamaan. Secara umum, petani merupakan pekerjaan utama para peternak tradisional di Indonesia. Hal ini juga ditemukan pada studistudi di daerah lain seperti di Kabupaten Kulon Progo (Hidayah et al., 2019), Kabupaten Enrekang (Halim, 2017), Kabupaten Magelang (Supriyanto et al,. 2020) dan pemeliharaan ternak sapi dapat dilakukan pada waktu senggang setelah peternak melakukan pekerjaan utama di lahan pertanian. Beberapa responden yang memiliki pekerjaan utama sebagai pedangang dan Pegawai Negeri Sipil (PNS) juga menjadikan usaha beternak sapi potong sebagai usaha sampingan. Sebagian kecil responden yaitu $1,25 \%$ yang memiliki pekerjaan utama sebagai peternak.

Pemeliharaan ternak sapi berfungsi sebagai tabungan dan untuk kepentingan adat istiadat. Fungsi ternak sebagai tabungan bertujuan untuk menyiapkan biaya pendidikan anak-anak di masa depan. Dengan demikian penjualan ternak sapi akan dilakukan pada saat dibutuhkan untuk pembiayaan pendidikan. Selain itu, ternak sapi akan digunakan juga pada kegiatan adat istiadat seperti mas kawin pada acara pernikahan dan sumber daging pada acara hajatan lainya. Hal ini menunjukkan bahwa beternak sapi merupakan usaha sampingan yang menjanjikan dan memberikan kontribusi yang signifikan dalam pendapatan. Sebaran pekerjaan utama peternak sapi potong di Kabupaten Sorong disajikan pada Tabel 3.

Tabel 3. Sebaran Pekerjaan Utama Responden di Sentra Produksi Ternak Potong di Kabupaten Sorong

\begin{tabular}{|c|c|c|c|c|c|c|}
\hline \multirow{2}{*}{ Pekerjaan Utama } & \multicolumn{4}{|c|}{ Responden/Distrik (Orang) } & \multirow{2}{*}{ Jumlah } & \multirow{2}{*}{ Persentase } \\
\hline & Mayamuk & Salawati & Moisigin & Segun & & \\
\hline Petani & 19 & 18 & 15 & 19 & 71 & 88,75 \\
\hline Peternak & 1 & 0 & 0 & 0 & 1 & 1,25 \\
\hline Pedagang & 0 & 0 & 1 & 0 & 1 & 1,25 \\
\hline Buruh Kasar & 0 & 0 & 1 & 0 & 1 & 1,25 \\
\hline PNS & 0 & 2 & 3 & 1 & 6 & 7,5 \\
\hline \multicolumn{5}{|c|}{ Total } & 80 & 100,00 \\
\hline
\end{tabular}

\section{PENGALAMAN BETERNAK}

Pada umumnya peternak memiliki pengalaman beternak sapi yang cukup lama. Sebagian besar peternak $(83,75 \%)$ telah memiliki pengalaman beternak lebih dari 10 tahun. Empat puluh persen peternak telah memiliki pengalaman beternak antara 10-20 tahun. Hal ini menunjukkan bahwa peternak cukup berpengalaman dalam memelihara ternak sapi. Pengalaman beternak yang cukup lama memberikan indikasi bahwa pengetahuan dan keterampilan beternak dan manajemen pemeliharaan ternak yang dimiliki petani semakin baik Menurut Tulle et al. (2005) bahwa pengalaman menentukan tingkat kedewasaan dan teknik dalam arti keterampilan dalam melakukan tugas-tugasnya. Pengetahuan dalam mengelola peternakan akan bertambah sejalan dengan bertambahnya pengalaman beternak. Lama beternak memberikan pengetahuan dan ketrampilan berdasarakan pengalaman beternak. Kecakapan ditentukan oleh pendidikan, pengetahuan dan pengalaman seseorang (Suratiyah, 2006). Lama beternak yang mengindikasikan pengalaman peternak dalam menjalankan usaha pemeliharaan ternak sapi potong di Kabupaten Sorong disajikan pada Tabel 4. 
Tabel 4. Sebaran Pengalaman di Sentra Produksi Ternak Potong di Kabupaten Sorong

\begin{tabular}{ccccccc}
\hline $\begin{array}{c}\text { Pengalaman } \\
\text { Beternak } \\
\text { (Tahun) }\end{array}$ & Mayamuk & Salawati & Moisigin & Segun & Jumlah & Persentase \\
\cline { 2 - 5 } $3-10$ & 4 & 1 & 4 & 4 & 13 & 16,25 \\
$11-20$ & 4 & 8 & 10 & 10 & 32 & 40,00 \\
$21-30$ & 4 & 7 & 4 & 4 & 19 & 23,75 \\
$31-40$ & 7 & 4 & 2 & 2 & 15 & 18,75 \\
$41-55$ & 1 & 0 & 0 & 0 & 1 & 1,25 \\
\hline & & Total & & & 80 & 100,00 \\
\hline
\end{tabular}

\section{JUMLAH KEPEMILIKAN TERNAK}

Usaha pemeliharaan sapi potong di Kabupaten Sorong pada umumnya merupakan usaha peternakan berskala kecil. Peternak sebagian besar $(91,25 \%)$ memiliki jumlah ternak sapi kurang dari 20 ekor. Namun demikian ada sebagian kecil $(2,50 \%)$ peternak yang termasuk dalam skala usaha menengah dengan jumlah kepemilikan ternak sapi lebih dari 30 ekor. Jumlah kepemilikan ternak sapi potong di Kabupaten Sorong disajikan pada Tabel 5.

Tabel 5. Sebaran Jumlah Kepemilikan Ternak di Sentra Produksi Ternak Potong di Kabupaten Sorong

\begin{tabular}{ccccccc}
\hline $\begin{array}{c}\text { Jumlah } \\
\text { Kepemilikan } \\
\text { Ternak (ekor) }\end{array}$ & Mayamuk & Salawati & Moisigin & Segun & Jumlah & Persentase \\
\cline { 2 - 5 } $3-10$ & 13 & 11 & 9 & 7 & 40 & 50,00 \\
$11-20$ & 7 & 7 & 9 & 10 & 33 & 41,25 \\
$21-30$ & 0 & 0 & 2 & 3 & 5 & 6,25 \\
$31-40$ & 0 & 1 & 0 & 0 & 1 & 1,25 \\
$41-60$ & 0 & 1 & 0 & 0 & 1 & 1,25 \\
\hline & \multicolumn{7}{c}{ Total } & & & 80 & 100,00 \\
\hline
\end{tabular}

Rendahnya jumlah kepemilikan sapi menunjukkan bahwa sebagian besar usaha pemeliharaan sapi potong dilakukan sebagai usaha sampingan. Aziz (1993) menyatakan bahwa pada tingkat pemeliharaan $<6$ ekor maka dikategorikan sebagai peternakan sapi potong baru bersifat dimiliki dan belum diusahakan. Biasanya ternak menentukan status sosial, serta pemasaran yang baru dilakukan apabila ada kebutuhan yang sangat mendesak untuk kepentingan yang bersifat sosial, budaya atau keagamaan. Selain itu ternak sapi berfungsi sebagai tabungan keluarga. Namun demikian peternak yang memelihara sapi potong umumnya berupaya meningkatkan usahanya dengan memperbaiki kualitas keturunan dan pakan agar produktivitas dari sapi potong yang dipelihara bisa lebih ditingkatkan.
Proporsi sapi jantan dan betina untuk tiga tahun terakhir cenderung tetap di sentra produksi ternak potong di Kabupaten Sorong. Proporsi jantan dan betina adalah 27,5\% dan $72,5 \%$. Sebagaimana Peraturan Menteri Pertanian Republik Indonesia Nomor 101/Permentan/OT.140/7/2014 tentang pedoman pembibitan sapi potong yang baik pada kawin alam, rasio jantan betina diusahakan 1:15-20 ekor. Tingginya populasi sapi betina disebabkan adanya aturan tidak boleh memotong sapi betina produktif. Hal lain yang diduga karena tujuan utama beternak adalah menambah jumlah ternak sapi yang dimiliki peternak sehingga memelihara sapi betina untuk tujuan reproduksi menjadi penting. Selain itu rendahnya populasi sapi jantan dapat juga diakibatkan tingginya pemotongan sapi jantan. Hal ini mengindikasikan peternak telah mengikuti 
aturan pembatasan pemotongan sapi betina produktif. Peningkatan populasi sapi jantan perlu ditingkatkan, sehingga kebutuhan protein hewani yang berasal dari ternak sapi untuk kabupaten Sorong dapat dipenuhi.

Tabel 6. Populasi Sapi Potong Berdasarkan Jenis Kelamin di Sentra Produksi Ternak Potong di Kabupaten Sorong

\begin{tabular}{lcccccc}
\hline \multirow{2}{*}{ Distrik } & \multicolumn{2}{c}{ Jantan } & \multicolumn{2}{c}{ Betina } & \multicolumn{2}{c}{ Total Populasi } \\
\cline { 2 - 7 } & ST & $\%$ & ST & $\%$ & ST & $\%$ \\
\hline Mayamuk & 1.168 & 28,8 & 2.891 & 71,2 & 4.059 & 100 \\
Salawati & 1.991 & 28,0 & 5.128 & 72,0 & 7.119 & 100 \\
Moisigin & 0.905 & 32,7 & 1.859 & 67,3 & 2.764 & 100 \\
Segun & 1.000 & 22,3 & 3.493 & 77,7 & 4.493 & 100 \\
\hline Total & 5.064 & 27,5 & 13.371 & 72,5 & 18.435 & 100 \\
\hline
\end{tabular}

\section{PERKandangan dan TEnaga KerJa}

Secara umum peternak memelihara ternak sapi secara ekstensif. Hal ini diindikasikan dengan tingginya proporsi sistem pemeliharaan ternak secara umbar dan ikat berpindah dibandingkan dengan sistem pemeliharaan lain. Selain itu, persentase kepemilikan kandang juga masih sangat kecil yaitu $26 \%$. Pola usaha peternakan sebagai usaha sampingan menjadikan sistem pemeliharaan yang semurah dan seminimal mungkin. Hal ini juga mengindikasikan bahwa peternak hanya menerapkan manajemen pemeliharaan yang masih minim. Rasyid dan Hartadi (2007), berpendapat bahwa kandang diperlukan untuk melindungi ternak dari perubahan cuaca dan iklim yang ekstrim, mencegah dan melindungi ternak dari penyakit, menjaga keamanan ternak dari pencurian, memudahkan pengelolaan ternak, serta meningkatkan efisiensi penggunaan tenaga kerja. Sistem pemeliharaan mencakup perkandangan sapi potong di Kabupaten Sorong selengkapnya tertera pada Tabel 7.

Tabel 7. Sistem Pemeliharan Sapi Potong di Sentra Produksi Ternak Potong di Kabupaten Sorong

\begin{tabular}{|c|c|c|c|c|c|c|}
\hline \multirow{2}{*}{ Sistem Pemeliharaan } & \multicolumn{4}{|c|}{ Responden/Distrik (Orang) } & \multirow{2}{*}{ Jumlah } & \multirow{2}{*}{ Persentase } \\
\hline & Mayamuk & Salawati & Moisigin & Segun & & \\
\hline Di kandangkan & 3 & 0 & 3 & 3 & 9 & 11,25 \\
\hline $\begin{array}{l}\text { Di kandangkan dan ikat } \\
\text { berpindah }\end{array}$ & 2 & 1 & 4 & 4 & 11 & 13,75 \\
\hline Di umbar & 5 & 6 & 7 & 7 & 25 & 31,25 \\
\hline $\begin{array}{l}\text { Di umbar dan ikat } \\
\text { berpindah }\end{array}$ & 2 & 0 & 2 & 2 & 6 & 7,50 \\
\hline Ikat berpindah & 8 & 13 & 4 & 4 & 29 & 36,25 \\
\hline \multicolumn{5}{|c|}{ Total } & 80 & 100,00 \\
\hline
\end{tabular}

Secara umum peternak menggunakan tenaga kerja keluarga dalam kegiatan usaha peterankan sapi potong. Hal ini diindikasikan dengan sebagian besar peternak $(97,5 \%)$ tidak memiliki tenaga kerja yang berasal dari luar keluarga untuk kegiatan usaha sapi potong. Peternak yang memiliki populasi sapi cukup tinggi (lebih dari 30 ekor) yang menggunakan tenaga kerja dari luar keluarga. Riszqina (2014) menyatakan bahwa semakin banyak jumlah ternak yang dipelihara semakin banyak waktu yang harus digunakan untuk mencari pakan dan membersihkan kandang. Peternak menggangap penggunaan tenaga kerja keluarga untuk pemeliharaan ternak sapi tidak termasuk dalam biaya yang perlu dikeluarkan peternak. Hal ini disebabkan karena peternak tidak perlu membayar tenaga kerja keluarga. Selain itu, jumlah kepemilikan sapi yang sedikit menyebabkan pengelolaan usaha ternak sapi 
dapat dilakukan keluarga secara mandiri. Usaha pemeliharan ternak sapi secara mandiri oleh anggota keluarga menyebabkan sistem pemiliharaan yang sangat minimal dimana peternak hanya melakukan sistem pemiliharaan secara umbar dan diikat berpindah.

Tabel 8. Sebaran Penggunaan Tenaga Kerja oleh Peternak di Sentra Produksi Ternak Potong di Kabupaten Sorong

\begin{tabular}{lccrrrr}
\hline Penggunaan & \multicolumn{2}{c}{ Responden/Distrik (Orang) } & & & Jumlah & Persentase \\
\cline { 2 - 6 } Tenaga Kerja & Mayamuk & Salawati & Moisigin & Segun & & \\
\hline Tidak & 20 & 19 & 19 & 20 & 78 & 97,50 \\
Ada & 0 & 1 & 1 & 0 & 2 & 2,50 \\
\hline Total & & & & & 80 & 100,00 \\
\hline
\end{tabular}

\section{PAKAN DAN PENGOBATAN}

Peternak sapi potong telah memberikan pakan tambahan selain pakan utama yang dikonsumsi langsung oleh ternak sapi. Sebagian besar peternak $(88,75 \%)$ memberikan pakan tambahan satu atau dua kali per hari. Namun demikian, terdapat sebagian kecil $(11,25 \%)$ peternak yang tidak memberikan pakan tambahan. Pemberian pakan berupa limbah pertanian menunjukkan kesadaran peternak akan kebutuhan pakan ternak sapi yang dipeliharanya. Peternak juga menyadari terbatasnya pakan yang dapat diperoleh ternak sapi secara langsung dengan sistem pemeliharaan secara ekstensif. Tindakan pemberian pakan berupa limbah pertanian juga mengindikasikan bahwa peternak mengusahakan agar pertumbuhan sapinya lebih baik dengan memberikan pakan limbah pertanian. Pemberian pakan limbah pertanian dilakukan apabila limbah pertanian tersedia. Frekuensi pemberian hijauan yang lebih sering dilakukan dapat meningkatkan kemampuan ternak sapi untuk mengonsumsi ransum dan juga meningkatkan kencernaan bahan kering hijauan (Wahyuni dan Amin, 2020). Frekuensi pemberian pakan yang dilakukan oleh peternak di Kabupaten Sorong disajikan pada Tabel 9.

Tabel 9. Frekuensi Pemberian Pakan Ternak Sapi Potong di Sentra Produksi Ternak Potong di Kabupaten Sorong

\begin{tabular}{lcrrrrr}
\hline \multicolumn{1}{c}{ Pemberian } & \multicolumn{4}{c}{ Responden/Distrik (orang) } & \multirow{2}{*}{ Jumlah } & \multirow{2}{*}{ Persentase } \\
\cline { 2 - 5 } Pakan (kali/hari) & Mayamuk & Salawati & Moisigin & Segun & & \\
\hline Satu kali & 6 & 4 & 8 & 8 & 26 & 32,50 \\
Dua kali & 10 & 15 & 10 & 10 & 45 & 56,25 \\
Tidak di berikan & 4 & 1 & 2 & 2 & 9 & 11,25 \\
\hline Total & & & & & 80 & 100,00 \\
\hline
\end{tabular}

Pakan ternak sapi berupa hijauan bersumber dari beberapa tempat seperti padang rumput, pinggir jalan, sawah, perkebunan, tepi jalan, dan tegalan. Sebagian besar peternak mendapatkan hijauan pakan ternak dari tepi jalan pada semua distrik dengan persentase diatas $58,75 \%$. Sumber pakan ternak sapi yang umum dimanfaatkan peternak adalah padang rumput dengan presentase $38,75 \%$. Padang rumput yang dimaksud peternak adalah rumput yang ditanam di pinggiran lahan pertanian dan tepian jalan. Pada umumnya rumput yang ditanam memiliki kualitas yang cukup tinggi.
Namun ketersedian hijauan dari kebun rumput ini sangat terbatas sehingga peternak masih memanfaatkan sumber hijauan seperti tepi jalan dan sumber hijauan pakan yang lain. Perlu adanya upaya penyediaan pakan dilakukan secara komprehensif dengan menerapkan konsep feed forage budgeting, perawatan dan pemanfaatan hijauan yang ada, pengembangan hijauan unggul, pengembangan usaha integrasi antara ternak dan tanaman pangan atau perkebunan dan penggalian potensi pakan lokal (Marsetyo, 2008). 
Pemenuhan kebutuhan pakan ternak masih lebih mengutamakan kuantitas, peternak belum memperhatikan kualitas hijauan yang diberikan. Hal ini diindikasikan dengan pemberian hijauan yang bersumber dari pinggiran jalan yang secara kualitas cukup rendah. Namun demikian peternak menyadari jumlah pakan yang dikonsumsi ternak masih terbatas sehingga peternak memberikan pakan tambahan yang bersumber dari beberapa areal. Penanaman hijauan pakan juga dilakukan peternak meskipun dalam skala kecil untuk memenuhi kebutuhan hijauan pakan ternak sapi. Pemanfaatan limbah pertanian sebagai pakan ternak merupakan alternatif sumber pakan yang cukup potensial. Tawaf dan Kuswaryan (2006) menyatakan bahwa sentrasentra pengembangan industri pertanian hendaknya bersinergi dengan kawasan peternakan. Sumber pakan ternak sapi potong yang terdapat di Kabupaten Sorong disajikan pada Tabel 10.

Tabel 10. Sumber Pakan Ternak Sapi Potong di Sentra Produksi Ternak Potong di Kabupaten Sorong

\begin{tabular}{|c|c|c|c|c|c|c|}
\hline \multirow{2}{*}{ Sumber Pakan } & \multicolumn{4}{|c|}{ Responden (Orang)/Distrik } & \multirow{2}{*}{ Jumlah } & \multirow{2}{*}{$\%$} \\
\hline & Mayamuk & Salawati & Moisigin & Segun & & \\
\hline Padang rumput & 7 & 9 & 9 & 6 & 31 & 38,75 \\
\hline Sawah & 5 & 9 & 0 & 0 & 14 & 17,50 \\
\hline Perkebunan & 0 & 3 & 0 & 0 & 3 & 3,75 \\
\hline Tepian jalan & 10 & 13 & 11 & 13 & 47 & 58,75 \\
\hline Tegalan & 0 & 9 & 4 & 2 & 15 & 18,75 \\
\hline Ranch & 3 & 0 & 3 & 5 & 11 & 13,75 \\
\hline
\end{tabular}

Pemeriksaan kesehatan ternak sangat jarang dilakukan di keempat distrik sentra ternak sapi potong di Kabupaten Sorong. Hal ini diindikasikan dengan tingginya persentase peternak yang tidak pernah melakukan pemeriksaan kesehatan $(80 \%)$ dalam kurun satu tahun terakhir. Dua puluh persen peternak pernah melakukan pemeriksaan ternaknya 1-3 kali dalam satu tahun terakhir (Tabel 11). Rendahnya pemeriksaan ternak disebabkan karena terbatasnya informasi pemeriksaan ternak sapi yang diterima peternak. Peternak tidak mendapatkan informasi dari dinas peternakan maupun dokter hewan tentang pemeriksaan kesehatan maupun pemberian obat-obatan pada ternak sapi. Untuk penanganan kesehatan, sebagian peternak memutuskan untuk membeli obat-obatan secara mandiri, dan diberikan kepada ternaknya sesuai dengan pengetahuan dan pengalamannya. Ada juga sebagian peternak yang menggunakan obat-obatan herbal yang dibuatnya sendiri untuk mengobati ternaknya. Menurut Berata et al. (2019) pelayanan kesehatan ternak sapi, yaitu upaya memberikan bantuan mengatasi berbagai penyakit pada ternak sapi sekaligus memberikan contoh kepada peternak dalam melakukan penanganan penyakit sapi.

Tabel 11. Frekwensi Pemeriksaan Kesehatan Ternak Sapi Potong dalam Satu Tahun Terakhir di Sentra Produksi Ternak Potong di Kabupaten Sorong

\begin{tabular}{|c|c|c|c|c|c|c|}
\hline \multirow{2}{*}{$\begin{array}{l}\text { Pemeriksaan } \\
\text { Kesehatan } \\
\text { (kali/tahun) }\end{array}$} & \multicolumn{4}{|c|}{ Responden (Orang)/Distrik } & \multirow{2}{*}{ Jumlah } & \multirow{2}{*}{$\%$} \\
\hline & Mayamuk & Salawati & Moisigin & Segun & & \\
\hline 1 kali & 3 & 0 & 3 & 3 & 9 & 11,25 \\
\hline 2 kali & 0 & 1 & 0 & 0 & 1 & 1,25 \\
\hline$>3$ kali & 1 & 4 & 0 & 0 & 5 & 6,25 \\
\hline Tidak ada & 16 & 15 & 17 & 17 & 65 & 81,25 \\
\hline \multicolumn{5}{|c|}{ Total } & 80 & 100,00 \\
\hline
\end{tabular}




\section{PERMODALAN}

Pada umumnya peternak menggunakan modal sendiri untuk usaha ternak sapi potong. Sebagian besar $(68,75 \%)$ sumber modal usaha awa untuk beternak sapi berasal dari uang pribadi peternak itu sendiri. Hal ini menunjukkan bahwa tingkat kesadaran petani akan meningkatnya pendapatan dengan memelihara ternak sapi cukup tinggi. Namun demikian terdapat juga sebagian peternak sapi yang mendapat dukungan modal yang berasal dari bantuan pemerintah $(31,25 \%)$ (Tabel 12). Rusdiana dan Praharani (2019) menyatakan bahwa pemerintah perlu mendorong investasi usaha ternak dan melakukan pemberdayaan peternak, sehingga peternak mampu mencapai kelayakan usaha dan pendapatan peternak meningkat. Pemberdayaan peternak yang diwadahi oleh kelembagaan peternakan dapat menekan aspek kerentanan usaha ternak dan meningkatkan posisi daya tawar peternak (Amam dan Solikin, 2020).

Usaha ternak sapi dianggap penting bagi petani sebagai usaha sampingan dan tabungan keluarga. Soetriono et al. (2019) menyatakan bahwa kondisi tersebut disebabkan oleh banyaknya masyarakat yang memelihara ternak sapi potong, namun tidak dilakukan dengan orientasi bisnis, melainkan hanya sebagai tabungan peternak, sebab berkaitan erat dengan sikap dan motivasi peternak (Harsita dan Amam, 2019). Sumber modal usaha ternak sapi potong di Kabupaten Sorong disajikan pada Tabel 12.

Tabel 12. Sumber Modal Usaha Ternak Sapi Potong di Sentra Produksi Ternak Potong di Kabupaten Sorong

\begin{tabular}{lrrrrrr}
\hline \multirow{2}{*}{ Sumber Ternak } & \multicolumn{4}{c}{ Peternak/Distrik (Orang) } & \multirow{2}{*}{ Jumlah } & Presentase \\
\cline { 2 - 5 } & Mayamuk & Salawati & Moisigin & Segun & & \\
\hline Bantuan Pemerintah & 10 & 7 & 4 & 4 & 25,00 & 31,25 \\
Modal Sendiri & 10 & 13 & 16 & 16 & 55,00 & 68,75 \\
\hline \multicolumn{2}{c}{ Total } & & & & 80.00 & 100,00 \\
\hline
\end{tabular}

\section{KORELASI ANTAR FAKTOR DEMOGRAFIS}

Hubungan antar faktor demografis yang menggambarkan keterkaitan antar karakteristik peternak dianalisis lebih lanjut. Hasil analisis korelasi pada penelitian ini terdiri atas variabel umur, pengalaman beternak, jumlah ternak dan luas lahan sebagaimana tertera pada Tabel 13.

Tabel 13. Hasil Analisis Korelasi Faktor Demografis

\begin{tabular}{lccccc}
\hline \multicolumn{1}{c}{ Korelasi Variabel } & Gradient & Konstanta & Korelasi & $\begin{array}{l}\text { Koefiesien } \\
\text { korelasi (r) }\end{array}$ & Regresi sederhana \\
\hline $\begin{array}{l}\text { Umur - jumlah ternak } \\
\begin{array}{l}\text { Pengalaman Beternak - } \\
\text { Jumlah Ternak }\end{array}\end{array}$ & 0,118 & 0,117 & 0,122 & 0,015 & $\mathrm{Y}=0,12 \mathrm{x}+0,12$ \\
$\begin{array}{l}\text { Luas Lahan- Jumlah } \\
\text { Ternak - }\end{array}$ & 0,028 & 0,0268 & 0,029 & 0,045 & $\mathrm{Y}=0,03 \mathrm{x}+0,02$ \\
$\begin{array}{l}\text { Pendidikan-Pemeriksaan } \\
\text { kesehatan }\end{array}$ & 0,082 & 0,090 & 0,089 & 0,088 & $\mathrm{Y}=0,089 \mathrm{x}+0,09$ \\
$\begin{array}{l}\text { Pendidikan -jumlah } \\
\text { ternak }\end{array}$ & 0,473 & 0,095 & 0,093 & 0,093 & $\mathrm{Y}=0,081 \mathrm{x}+0,094$ \\
\hline
\end{tabular}

Pengalaman beternak, pendidikan, umur memiliki hubungan dengan jumlah ternak yang dipelihara. Hal ini ditunjukkan dengan nilai koefiesien korelasi $(r<0.05)$. Namun nilai $r$ menunjukkan pengalaman beternak dan pendidikan memiliki keeratan hubungan yang tidak terlalu kuat terhadap variabel jumlah ternak sapi potong. Hal ini berarti semakin lamanya pengalaman beternak tidak menjamin jumlah ternak yang dipelihara akan semakin banyak. Demikian halnya juga tingkat pendidikan peternak. Peningkatan jumlah 
ternak seiring dengan lamanya pengalaman beternak dalam hal ini disebabkan tujuan beternak yang sifatnya tabungan dan pengembangbiakan. Karakteristik lamanya pengalaman beternak tidak serta merta menjamin jumlah ternak yang semakin banyak dengan sistem peternakan rakyat yang pengelolaanya masih sebagai usaha sampingan. Menurut Iskandar dan Arfa'i (2007), umur dan pengalaman beternak akan mempengaruhi kemampuan peternak dalam menjalankan usaha peternakannya. Peternak yang memiliki pengalaman yang lebih tinggi, akan selalu berhati-hati dalam bertindak dan menjadikan pengalaman buruk masa lalu sebagai penyemangat untuk berubah. Selanjutnya menurut Tulle et al. (2005), bahwa pengalaman menentukan tingkat kedewasaan dan teknik dalam arti keterampilan dalam melakukan tugas-tugasnya. Selain itu banyaknya jumlah ternak memiliki pengaruh terhadap pendapatan (Raditya, 2006).

Faktor luas lahan tidak mempengaruhi jumlah ternak yang dipelihara Hal ini dikarenakan sistem pemeliharaan yang dilakukan peternak dominan dengan sistem umbar terbatas dan pemberian pakan ditambah dari sumber lain seperti pinggir jalan dan sumber lain. Selain itu 50\% peternak memiliki jumlah ternak dibawah 10 ekor yang tidak memerlukan lahan luas untuk pemeliharaanya. Aziz (1993) menyatakan bahwa pada tingkat pemeliharaan $<6$ ekor dikategorikan sebagai peternak sapi potong baru bersifat dimiliki dan belum diusahakan. Tingkat pendidikan peternak tidak menggambarkan hubungan keterkaitan yang erat dengan manajemen peternakan seperti pemeriksaan kesehatan. Hal ini mengindikasikan peternak memiliki kesadaran yang sama dalam pemerikasaan kesehatan ternak. Kesehatan ternak berdampak secara tidak langsung pada peningkatan populasi ternak. Dengan demikian tingkat pendidikan tidak dapat digunakan sebagai acuan untuk usaha peningkatan populasi ternak sapi potong di Kabupaten Sorong.

\section{KESIMPULAN}

Berdasarkan hasil penelitian, maka disimpulkan sebagai berikut: (1) Umur peternak berada pada usia produktif dengan tingkat pendidikan yang cukup rendah. (2) Usaha peternakan masih dalam kategori skala memiliki, belum berorientasi usaha dengan manajemen pemeliharaan minimal dalam pemberian pakan, perkandangan dan kesehatan. (3) Pengalaman beternak, umur dan pendidikan memiliki keeratan hubungan yang tidak terlalu kuat terhadap variabel jumlah ternak sapi potong. (4) Faktor luas lahan tidak mempengaruhi jumlah ternak yang dipelihara.

\section{DAFTAR PUSTAKA}

BPS (Badan Pusat Statistik). 2019. Kabupaten Sorong Dalam Angka. BPS, Papua Barat https://sorongkab.bps.go.id - 22 Agustus 2020.

BPS (Badan Pusat Statistik). 2020. Populasi Ternak Sapi di Provinsi Papua Barat Tahun 2015 - 2018. https://papuabarat.bps.go.id 26 Mei 2020.

Budiharsono dan Sugeng. 2001. Teknis Analisis Pembangunan Wilayah Pesisir dan Lautan. PT. Pradnya Paramita. Jakarta.

Dinas Peternakan dan Kesehatan Hewan. 2019. Populasi Ternak Sapi di Kabupaten Sorong Tahun 2019. Laporan Dinas Peternakan dan Kesehatan Hewan.

Direktorat Jenderal Peternakan dan Kesehatan Hewan. 2018. Statistik Peternakan dan Kesehatan Hewan. Populasi Sapi Potong $\begin{array}{llll}\text { Tahun } & 2014 \quad & - & 2018 .\end{array}$ https://ditjennak.pertanian.go.id - $25 \mathrm{Mei}$ 2020.

Fariani A. 2008. Pengembangan Ternak Ruminansia Berdasarkan Ketersediaan Lahan Hijauan dan Tenaga Kerja di Kabupaten Musi Rawas, Sumatera Selatan. J. Indon.Trop. Agric., 33(2):145 - 157.

Halim S. 2017. Pengaruh Karakteristik Peternak Terhadap Motivasi Beternak Sapi Potong Di Kelurahan Bangkala Kecamatan Maiwa. [Skripsi]. Fakultas Peternakan, Universitas Hasanuddin Makassar

Hartono B. 2012. Peran Daya Dukung Wilayah Terhadap Pengembangan Usaha Peternakan Sapi Madura. Jurnal Ekonomi Pembangunan. 13(2): 316-326.

Hendayana R. 2003. Aplikasi Metode Location Questiont (LQ) Dalam Penentuan Komoditas Unggulan Nasional. Informatika Pertanian. 12: 1-21. 
Hidayah N, Artdita CA dan Lestari FB. 2019. Pengaruh Karakteristik Peternak Terhadap Adopsi Teknologi Pemeliharaan pada Peternak Kambing Peranakan Ettawa di Desa Hargotirto Kabupaten Kulon Progo. Jurnal Bisnis dan Manajemen (Journal of Business and Management). 19(1): 1-10.

Murwanto, A.G. 2008. Karakteristik Peternak dan Tingkat Masukan Teknologi Peternakan Sapi Potong di Lembah Prafi Kabupaten Manokwari. Jurnal Ilmu Peternakan. 3(1): 8 - 15.

Nurlaila S, Riszqina, Suparno dan Heryadi AY. 2017. Daya Dukung Pengembangan Ternak Sapi Potong di Kabupaten Pamekasan. Fakultas Pertanian Universitas Madura Pamekasan. Seminar Nasional Peternakan 3 tahun. Universitas Hasanuddin Makassar, 18 September 2017.

Padmowihardjo S. 1978. Beberapa Konsepsi Proses Belajar dan Implikasinya. [Makalah]. Institut Pendidikan Latihan dan Penyuluhan Pertanian Ciawi. Bogor.

Riszqina. 2014. Performa Usaha Ternak Sapi Madura Sebagai Sapi Potong, Sapi Karapan dan Sapi Sonok di Pulau Madura. Ringkasan Disertasi. Program Studi Doktor Ilmu Peternakan Program Pascasarjana Fakultas Peternakan dan Pertanian Universitas Diponegoro, Semarang.
Santosa SI, Setiadi A dan Wulandari R. 2013. Analisis Potensi Pengembangan Usaha Peternakan Sapi Perah dengan Menggunakan Paradigma Agribisnis di Kecamatan Musuk Kabupaten Boyolali. Buletin Peternakan. 37(2): 125-135.

Setiawan, N. 2007. Penentuan Ukuran Sampel Memakai Rumus Slovin dan Tabel KrejcieMorgan: Telaah Konsep Dan Aplikasinya. Makalah disampaikan pada Diskusi Ilmiah Jurusan Sosial Ekonomi Fakultas Peternakan Universitas Padjadjaran, Bandung.

Supriyanto, Fidin NI, Nurdayati dan Zuliyana I. 2020. Pengaruh Karakteristik Peternak Terhadap Motivasi Beternak di Desa Kalirejo,

Kecamatan Salaman, Kabupaten Magelang. Prosiding Seminar Nasional. Polbangtan Yogyakarta Magelang.

Tomatala GSJ. 2004. Pemanfaatan Media Komunikasi Dan Perilaku Usaha Peternak Sapi Potong. Kasus Kecamatan Sukanagara, Kabupaten Cianjur. [Tesis]. Bogor: Institut Pertanian Bogor.

Wardhani A. 1994. Hubungan Karakteristik Demografis dan Motivasi Peternak dengan Penggunaan sumber-Sumber Informasi Tentang Ayam Buras Di Desa Cisontrol, Kabupaten Ciamis. [Tesis]. Bogor: Institut Pertanian Bogor. 